\title{
Chemical and morphological analysis of kidney stones. A double-blind comparative study ${ }^{1}$
}

\author{
Análise química e morfológica de cálculos renais. Estudo comparativo duplo-cego
}

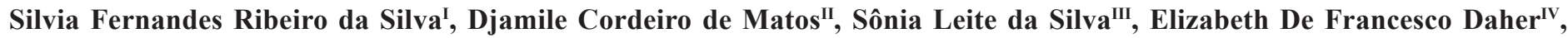 \\ Henry de Holanda Campos ${ }^{I V}$, Carlos Antonio Bruno da Silva ${ }^{\mathrm{V}}$
}

\author{
${ }^{\mathrm{I}}$ Fellow PhD degree, Post-graduate Program in Health Sciences, Federal University of Rio Grande do Norte (UFRN), Natal. Assistant Professor, \\ University of Fortaleza and Pharmacist, Federal University of Ceara (UFC), Brazil. \\ II Master, Pharmacist, University of Fortaleza, Ceara, Brazil. \\ ${ }^{\text {III }} \mathrm{PhD}$, Assistant Professor, University of Fortaleza. Doctor, UFC, Ceara, Brazil. \\ Iv PhD, Full Professor, UFC, Ceara, Brazil. \\ ${ }^{v}$ PhD, Full Professor, University of Fortaleza. Associate Professor, Post-graduate Program in Health Sciences, UFRN, Natal, Brazil.
}

\begin{abstract}
Purpose: To compare chemical to morphological kidney stone composition analysis based on a sample of 50 stones retrieved from patients at a nephrology service. Methods: The chemical analysis was performed with a Bioclin ${ }^{\circledR}$ kit, while a 10 -mm magnifying glass (10x; Prolabo, Paris, France) was employed in the morphological analysis. Findings obtained with the two methods were compared and classified as concordant (100\% agreement), partly concordant (concordant for major components, discordant for minor components) or discordant (discordant for major components). Results: In the chemical analysis, the most commonly observed major component was calcium $(70 \%)$, followed by oxalate $(66 \%)$, ammonium $(56 \%)$, urate $(28 \%)$ and carbonate $(24 \%)$. In the morphological analysis, the most commonly observed major components were calcium phosphate and magnesium (32\% each), followed by calcium oxalate monohydrate $(24 \%)$, uric acid and urates $(20 \%$ each), calcium oxalate dihydrate $(18 \%)$ and cystine $(6 \%)$. Infectious kidney stones were identified in $34 \%$ and $24 \%$ of cases by morphological and chemical analysis, respectively. Thirty-eight percent of the samples were classified as concordant, $52 \%$ were partly concordant and 10\% were discordant. Conclusion: We suggest kidney stones be routinely submitted to both types of analysis for a better understanding of the mechanisms involved in lithogenesis.
\end{abstract}

Key words: Morphology. Urinary Calculi. Urinary Bladder Calculi.

\section{RESUMO}

Objetivo: Comparar a análise química com a análise morfológica de 50 cálculos urinários provenientes de pacientes em um serviço de nefrologia. Métodos: A análise química foi realizada utilizando o kit da Bioclin ${ }^{\circledR}$, enquanto que a morfológica foi realizada com auxílio de uma lupa de 10mm (Prolabo, Paris, France). A comparação entre as técnicas foi classificada em concordante (100\% de concordância), parcialmente concordante (componentes majoritários concordantes e minoritários discordantes) e discordante (discordância nos componentes majoritários). Resultados: Na análise química os principais componentes majoritários foram cálcio (70\%), oxalato (66\%), amônio (56\%), urato $(28 \%)$ e carbonato $(24 \%)$. Na análise morfológica os principais componentes majoritários foram fosfato cálcico (PCa) e magnesiano-PCa (32\%), oxalato de cálcio monohidratado (24\%), ácido úrico e uratos (20\%), oxalato de cálcio dihidratado (18\%) e cistina (6\%). Cálculos de infecção foram identificados em $34 \%$ e $24 \%$ casos pela análise morfológica e química, respectivamente. Concordância total foi observada em 38\%, concordância parcial em $52 \%$ e discordância em $10 \%$. Conclusão: Sugere-se a utilização simultânea das duas técnicas para melhor compreensão dos mecanismos litogênicos.

Descritores: Morfologia. Cálculos Urinários. Cálculos da Bexiga Urinária.

${ }^{1}$ Research performed at Center for Research in Hepatic and Renal Diseases, Fortaleza-CE, Brazil.

\section{Introduction}

Urinary lithiasis is a common condition currently affecting $4-20 \%$ of the world population ${ }^{1,2}$. The risk of a normal adult developing lithiasis ranges from low to high: $1-5 \%$ in Asia, $5-9 \%$ in Europe, $13 \%$ in the US and $20.1 \%$ in Saudi Arabia ${ }^{3}$.
In Brazil, 5-10\% of the population suffers from urinary lithiasis. The main related metabolic changes observed are hypercalciuria, hyperoxaluria, hyperuricosuria, hypocitraturia and hypomagnesiuria ${ }^{4-6}$. These metabolic disorders are risk factors for lithiasis, but may occur in patients who never develop kidney stones. The best indicator-and only gross evidence-of lithiasis is kidney stones formed in the urinary system ${ }^{7,8}$. 
In Northeastern Brazil few studies have attempted to characterize urinary lithiasis based on kidney stone composition analysis, partly because the services of most local laboratories are limited to chemical analysis, which yields insufficient data. Thus, the objective of the present study was to compare chemical to morphological kidney stone composition analysis based on a sample of 50 stones retrieved from patients at a nephrology service.

\section{Methods}

This was a cross-sectional, double-blind study comparing chemical to morphological kidney stone composition analysis based on a sample of 50 stones retrieved from patients referred to the Crystalluria Research Laboratory, Center for Hepatic and Renal Diseases - a division of the Federal University of Ceara (Fortaleza, Brazil).

The chemical analysis and the morphological analysis were carried out by two different professionals blinded to each other's findings.

\section{Chemical analysis}

The chemical analysis was performed with a Bioclin ${ }^{\circledR}$ kit. Initially the stones were fragmented and pulverized in a porcelain crucible. The powder was homogenized, placed in a test tube and immersed in a water bath at $56^{\circ} \mathrm{C}$ for 5 minutes, followed by centrifugation at 3,000 rpm for 3 minutes. The precipitate was left in the original tube while the supernatant was removed to a second test tube. The precipitate was analyzed for the presence of carbonate, oxalate, calcium and magnesium, while the supernatant was tested for urate, cystine, ammonium and phosphate. Once the analyses were completed, the results were interpreted according to the instructions of the manufacturer of the kit (checking positive or negative for each stone component).

\section{Morphological analysis}

The morphological analysis was conducted in accordance with the protocol published by Daudon et $a l .{ }^{7}$. Initially the surface was analyzed with a 10-mm magnifying glass (Prolabo, Paris, France), then the stones were sectioned and the components of the core, middle layer and outer layer were identified. In the case of stones obtained by means of extracorporeal shock wave lithotripsy (ESWL), all fragments were analyzed to determine form and structure. Stones containing two or more components were classified as "mixed stones" and their major and minor components were identified. The cut-off between minor and major components was specified as $\geq 40 \%$.

\section{Definitions}

The findings of the chemical analysis were semiquantified in scores for greater comparability between the two methods of analysis. Very turbid samples and large amounts of precipitate were scored $3^{+}$or $4^{+}$and the component was classified as "major". Moderately or slightly turbid samples and small amounts of precipitate were scored as $1^{+}$or $2^{+}$and the component was classified as "minor". Stones containing phosphate, ammonium and magnesium were classified as infectious.

\section{Chemical versus morphological analysis}

Findings obtained with the two methods of composition analysis were compared and classified as concordant $(100 \%$ agreement), partly concordant (concordant for major components, discordant for minor components) or discordant (discordant for major components).

\section{Statistical analysis}

The data were entered into a Microsoft Excel spreadsheet and the qualitative and quantitative variables were analyzed using descriptive statistics (average, standard deviation, minimum and maximum values, and gross and percentage frequency).

\section{Ethics}

The protocol of the present study was previously approved by the Research Ethics Committee of the University of Fortaleza (UNIFOR, Fortaleza-CE, Brazil).

\section{Results}

\section{Subject profile}

The average age of the 50 patients in the sample was $36.9 \pm 16.5$ years $(4-74)$. Half the patients were female.

\section{Chemical analysis}

The chemical analysis revealed the following composition: calcium oxalate ( $\mathrm{CaOx}) \quad 32 \%$; oxalate + phosphate + ammonium + magnesium: $22 \%$; oxalate, oxalate+urate and oxalate+ + phosphate+calcium: $10 \%$ each; calcium phosphate $(\mathrm{CaP})$, calcium+urate, cystine+urate: $4 \%$ each; calcium, oxalate + urate + phosphate + cystine: $2 \%$ each .

Since the results of the chemical analysis were qualitative and the stones were pulverized prior to analysis, the composition of each stone layer could not be specifically determined.

In the chemical analysis the most frequently observed major components were calcium $(70 \%)$, oxalate $(66 \%)$, ammonium $(56 \%)$, urate $(28 \%)$ and carbonate $(24 \%)$. The most frequently observed minor components were ammonium (30\%), urate and magnesium (18\% each) and calcium (10\%). Cystine was the major chemical component in 2 stones (but the major morphological component in 3 stones). In the overall chemical analysis, ammonium was the major component in $86 \%$ of samples, followed by calcium $(80 \%)$, oxalate $(72 \%)$, uric acid $(46 \%)$, phosphate $(34 \%)$, carbonate $(28 \%)$, magnesium $(26 \%)$ and cystine $(6 \%)$ (Table 1$)$. 
TABLE 1 - Comparison of chemical and morphological findings of 50 kidney stones with regard to major and minor components

\begin{tabular}{cccc}
\hline Kidney stones & \multicolumn{2}{c}{ Components } & \\
\hline \hline Chemical analysis & Major & Minor & Total \\
\hline Calcium & $35(70 \%)$ & $5(10 \%)$ & $40(80 \%)$ \\
Oxalate & $33(66 \%)$ & $3(6 \%)$ & $36(72 \%)$ \\
Phosphate & $13(26 \%)$ & $4(8 \%)$ & $17(34 \%)$ \\
Carbonate & $12(24 \%)$ & $2(4 \%)$ & $14(28 \%)$ \\
Urate & $14(28 \%)$ & $9(18 \%)$ & $23(46 \%)$ \\
Magnesium & $4(8 \%)$ & $9(18 \%)$ & $13(26 \%)$ \\
Cystine & $2(4 \%)$ & $1(2 \%)$ & $3(6 \%)$ \\
Ammonium & $28(56 \%)$ & $15(30 \%)$ & $43(86 \%)$ \\
\hline Morphological analysis & Major & Minor & Total \\
\hline COM & $12(24 \%)$ & $4(8 \%)$ & $16(32 \%)$ \\
COD & $9(18 \%)$ & $7(14 \%)$ & $16(32 \%)$ \\
Uric acid and urate & $10(20 \%)$ & $2(4 \%)$ & $12(24 \%)$ \\
Calcium and magnesium & $16(32 \%)$ & $9(18 \%)$ & $25(50 \%)$ \\
phosphate & $3(6 \%)$ & $0 \%$ & $3(6 \%)$ \\
Cystine & $0 \%$ & $1(2 \%)$ & $1(2 \%)$ \\
Protein & & &
\end{tabular}

$\mathrm{COM}=$ calcium oxalate monohydrate; $\mathrm{COD}=$ calcium oxalate dihydrate

\section{Morphological analysis}

Table 2 shows the results of the morphological analysis. The components of the core, middle layer and outer layer were identified for $90 \%, 92 \%$ and $92 \%$ of the stones, respectively.

In the morphological analysis, the most frequently observed major components were magnesium and $\mathrm{CaP}(32 \%)$, followed by COM (24\%), uric acid and urates (20\%), COD (18\%) and cystine $(6 \%)$. Among the minor components, COM and COD were in inverse order and protein was observed: $\mathrm{CaP}(18 \%), \mathrm{COD}$ $(14 \%)$, COM $(8 \%)$, uric acid (4\%) and protein $(2 \%)$. Overall, $\mathrm{CaP}$ was found in $50 \%$ of the stones, followed by COM and COD $(32 \%$ each), uric acid $(24 \%)$, cystine $(6 \%)$ and protein $(2 \%)$ (Table 3).

TABLE 2 - Findings from the morphological analysis of 50 kidney stones analyzed according to the protocol of Daudon et al. ${ }^{7}$

\begin{tabular}{cccc}
\hline \multicolumn{4}{c}{ Kidney stones } \\
\hline Components & Core & Middle layer & Outer layer \\
\hline \hline COM & $13(26 \%)$ & $12(24 \%)$ & $9(18 \%)$ \\
COD & $8(16 \%)$ & $8(16 \%)$ & $11(22 \%)$ \\
Uric acid and urates & $9(18 \%)$ & $8(16 \%)$ & $9(18 \%)$ \\
Calcium and magnesium & $12(24 \%)$ & $15(30 \%)$ & $13(26 \%)$ \\
phosphate & $3(6 \%)$ & $3(6 \%)$ & $3(6 \%)$ \\
Cystine & $0(0 \%)$ & $0(0 \%)$ & $1(2 \%)$ \\
Protein & $5(10 \%)$ & $4(8 \%)$ & $4(8 \%)$ \\
ND & $50(100 \%)$ & $50(100 \%)$ & $50(100 \%)$ \\
\hline TOTAL & & & \\
\hline
\end{tabular}

$\overline{\mathrm{COM}}=$ calcium oxalate monohydrate; $\mathrm{COD}=$ calcium oxalate dihydrate; ND: not determined 
TABLE 3 - Agreement between chemical and morphological findings for 50 kidney stones

\section{Components Totally concordant Partly concordant}

\begin{tabular}{ccc}
\hline \hline $\mathrm{CaOx}$ & $10(52.5 \%)$ & $10(38.5 \%)$ \\
$\mathrm{CaP}$ & $1(5.3 \%)$ & $10(38.5 \%)$ \\
$\mathrm{CaOx}+\mathrm{CaP}$ & $2(10.6 \%)$ & 0 \\
Urate & $5(26.3 \%)$ & $4(15.3 \%)$ \\
Cystine & $1(5.3 \%)$ & $2(7.7 \%)$ \\
\hline Total & $19(38 \%)$ & $26(52 \%)$ \\
\hline
\end{tabular}

$\mathrm{CaOx}=$ calcium oxalate $\mathrm{CaP}=$ calcium phosphate

\section{Chemical and morphological analysis}

Infectious stones were identified by morphological analysis in 17 cases (34\%) and by chemical analysis in 12 $(24 \%)$ cases.

\section{Chemical versus morphological analysis}

The two methods of analysis were in total agreement in 19 cases (38\%), in partial agreement in $26(52 \%)$ cases and in disagreement in $5(10 \%)$ cases. Totally concordant stones consisted mainly of $\mathrm{CaOx}(52.5 \%)$ and urates $(26.3 \%)$ and more rarely of phosphates (CaP: $5.3 \%$; $\mathrm{CaP}+\mathrm{CaOx}: 10.6 \%)$ and cystine $(5.2 \%)$. Partly concordant stones consisted mainly of $\mathrm{CaOx}$ and $\mathrm{CaP}(38.5 \%$ each), followed by urate (15.4\%) and cystine (7.6\%). Urate was a minor component in $18 \%$ and $4 \%$ of the stones in the chemical and morphological analysis, respectively (partial agreement).

The two methods were in disagreement with regard to five stones $(10 \%)$ : Three of these were identified chemically as $\mathrm{CaP}$ and morphologically as uric acid $(\mathrm{n}=1)$ or $\mathrm{CaP}(\mathrm{n}=2)$, one was identified as calcium versus $\mathrm{CaP}$, and one was classified as $\mathrm{CaP}+$ struvite versus acid ammonium urate, respectively (Table 3).

\section{Discussion}

The formation of kidney stones involves three associated processes: nucleation, crystal aggregation and growth. Nucleation starts with the retention of an insoluble (not necessarily crystalline) substance in the kidney. Crystals then aggregate around this substance and the stone begins to grow, forming the layers observed in sectioned stones: core, middle layer and outer layer9. The study of these layers, as conducted in the present morphological analysis, provides a better understanding of the genesis of individual stones. Knowledge of the origin of the stone and the factors involved in the lithogenic process is helpful when prescribing a diet or therapy intended to reduce the risk of recurrence ${ }^{10,11}$. Without treatment, the risk of recurrence of $\mathrm{CaOx}$ stones is $10 \%$ in one year, $33 \%$ in 5 years and $50 \%$ in 10 years $^{12}$.
The determination of the major components of the stone is also important in the study of urinary lithiasis because the distribution of components provides data on the urinary environment and the pathology or abnormalities responsible for the lithogenic process ${ }^{8}$. In France the most frequently observed major component in kidney stones in adults is $\mathrm{CaOx}(70.2 \%)$, followed by $\mathrm{CaP}(13.4 \%)$ and uric acid $(9.7 \%)^{10}$. A similar distribution has been observed in a sample of 340 kidney stones from patients in Ceara (Brazil) ${ }^{13}$. It should be pointed out, however, that the objective of the present study was not to determine stone component distribution in a given sample but to compare two methods of composition analysis.

The major components of kidney stones are most often identified by morphological analysis. To accomplish the same by chemical analysis, we established the scores $3^{+}$and $4^{+}$for major components and the scores $1^{+}$and $2^{+}$for minor components. By using a similar system, laboratories providing chemical kidney stone analysis might with advantage include information on major and minor components in their reports.

The two main crystalline forms of $\mathrm{CaOx}$ are $\mathrm{COM}$ and $\mathrm{COD}^{3}$. Identifying the crystalline form is useful when planning therapy. Thus, COD is associated with hypercalciuria, but COM is more closely tied up with hyperoxaluria, making such stones more difficult to fragment by ESWL. In addition, COD is associated with higher recurrence rates than $\mathrm{COM}^{3,10,13}$. Unlike morphological analysis, chemical analysis detects calcium and oxalate separately and therefore cannot differentiate crystalline types of $\mathrm{CaOx}$. In this study, COM and COD were evenly distributed ( $32 \%$ each).

In cystine-containing stones identified by chemical analysis, urate was a major component while cystine was a minor component; however, in the morphological analysis, cystine was a major component. This suggests cystine stones may easily be confused with urate stones if submitted to chemical analysis only. Cystinuria is an autosomal recessive disorder affecting $1 \%$ of adults and $10 \%$ of children with kidney stones. In Brazil, screening for this disorder is usually done with sodium nitroprusside ${ }^{5,6}$. The test is considered positive when the concentration of cystine in the urine is above $100 \mathrm{mg} / \mathrm{L}^{14}$. In other words, kidney stone composition analysis can help diagnose cystinuria, especially in adults for whom the incidence is relatively low.

In five of the infectious stones in our sample the chemical analysis could not identify all the components (phosphate, ammonium and magnesium), making it difficult to interpret the results. To avoid recurrence, infectious stones should be identified and eliminated for improved control of urinary infection caused by urease-producing bacteria ${ }^{15}$. On the other hand, chemical analysis makes it possible to detect $\mathrm{CaOx}$ in stones composed of $\mathrm{CaP}$, especially struvite, thereby indicating the nature of the metabolic disorder responsible for lithiasis.

\section{Conclusion}

We suggest kidney stones be routinely submitted to chemical and morphological analysis for a better understanding of the mechanisms involved in lithogenesis. 


\section{References}

1. Moe OW. Kidney stones: pathophysiology and medical management. Lancet. 2006;367(9507):333-44.

2. Yasui T, Iguchi M, Suzuki S, Kohri K. Prevalence and epidemiological characteristics of urolithiasis in Japan: National trends between 1965 and 2005. Urology. 2008;71(2):209-13.

3. Bauzá AC, Ramis M, Montesinos V, Conte A, Pizá P, Pieras E, Grases F. Type of renal calculi: variation with age and sex. World J Urol. 2007;25(4):415-21.

4. Sakuno MLD, Aakimoto LS, Mereles EAL, Modenuti MI, Vieira AGM, Dalcol SMD. Contribuição do laboratório de análises clínicas no diagnóstico metabólico da litíase renal. Rev Bras Anal Clin. 1994;26(3):77-80.

5. Peres LAB, Molina AS, Galles MHL. Metabolic investigation of patients with urolithiasis in a specific region. Int Braz J Urol. 2003;29(3):217-20.

6. Amaro CR, Goldberg J, Amaro JL, Padobani CR. Metabolic assessment in patients with urinary lithiasis. Int Braz J Urol. 2005;31(1):29-33.

7. Daudon M, Bader CA, Junger P. Urinary calculi: review of classification methods and correlation with etiology. Scan Microsc. 1993;7(3):1081-106.
8. Djelloul Z, Djelloul A, Bedjaoui A, Kaid-Omar Z, Attar A, Daudon M, Addou A. Lithiase urinaire dans l'Ouest algérien: étude de la composition de 1354 calculs urinaires en relation avec leur localisation anatomique, l'âge et le sexe des patients. Progrès Urol. 2006;16:328-35.

9. Daudon M. Lithogenèse. In: Doré B. Les lithiases rénales. França: Springer-Verlag; 2004. p.31-47.

10. Daudon M. Épidémiologie actuelle de la lithiase rénale en France. Ann Urol. 2005;39(6):209-31.

11. Heilberg IP, Schor N. Renal stone disease: causes, evaluation and medical treatment. Arq Bras Endocrinol Metab. 2006;50(4):823-31.

12. Sellaturay S, Fry C. The metabolic basis for urolithiasis. Surgery. 2008;26(4):136-40.

13. Silva SFR, Silva SL, Daher EF, Silva Junior GB, Mota RMS, Silva CAB. Determination of urinary stone composition based on stone morphology: a prospective study of 235 consecutive patients in an emerging country. Clin Chem Lab Med. 2009;47(5):561-4.

14. Jungers P, Joly D, Gagnadoux MF, Daudon M. Lithiase cystinique: physiopathologie et traitement medical. Prog Urol. 2001;11(1):122-6. 15. Rieu P. Lithiases d'infection. Ann Urol. 2005;39(1):16-29.

Conflict of interest: none Financial source: none

\section{Correspondence:}

Carlos Antônio Bruno da Silva

Universidade de Fortaleza

Av. Washington Soares, 1321/Bloco C, sala C07

60811-905 Fortaleza - CE Brasil

carlosbruno@unifor.br

Received: February 23, 2010

Review: April 20, 2010

Accepted: May 19, 2010

\section{How to cite this article}

Silva SFR, Matos DC, Silva SL, Daher EF, Campos HH, Silva CAB. Chemical and morphological analysis of kidney stones. A double-blind comparative study. Acta Cir Bras. [serial on the Internet] 2010 Sept-Oct;25(5). Available from URL: http://www.scielo.br/acb 